\title{
From Business Administration to Business Creation: The Case of the Kalevala Global Business Creation School

\author{
Marko Seppä
}

\author{
"The greater the loyalty of a group toward the group, the greater") \\ is the motivation among the members to achieve the goals of \\ the group, and the greater the probability that the group will \\ achieve its goals.
}

Rensis Likert (1903-1981)

Organizational Psychologist

\begin{abstract}
Are there any businesses left to administer? The question is of course rhetorical and aimed at underscoring how several societies are more severely in need of creators of new businesses than managers of established ones. And yet, nearly all universities only produce masters of business administration, at best. Apart from theoretical research about business creation, and the education of masters of such research, universities are generally not equipped to produce knowledge for business creation or to produce masters of business creation.
\end{abstract}

This conceptual article calls for a new, complementary approach to research and education, around the theme of global business creation. Due to the limitations and restrictions related to the traditions and practices of the science of business administration, where the means justify the ends, a new exploratory field coined as the "Art of Business Creation," where the end justifies the means, is being explored for some inspiration.

For a concrete solution, the concept of a globally distributed, enterprise-centric, entrepreneurial-faculty-driven, open-innovation-based, and social-media-empowered university entity is depicted in this article. It is a new-generation private-public-partnership and "Living Lab 2.0" referred to as Kalevala Global Business Creation School. The conceptualization draws from observations and action research during the Global Venture Lab Finland experiment at the University of Jyväskylä from 2007 to 2011.

\section{Introduction}

The University is the ultimate knowledge factory. Nations compete, among other things, on the quantity of academic and scholarly knowledge created. Research and development expenditure, as a percentage of GDP, is an established macro-level measure of innovation and so is the number of patents. The university system accounts for a lot of the quantity.
But what is the economic value of the knowledge and the "knowledgists" produced? There are measures, education, and support readily available for those who invent and publish - either patents or journal papers but less such support for those who commercialize and turn innovative ideas, technologies, or processes into world brands. Should not The University produce knowledge and "knowledgists" that bridge theory and the real world within the business-creation domain as well? 


\title{
The Case of the Kalevala Global Business Creation School
}

\author{
Marko Seppä
}

Even the greatest invention and research result is economically worthless, unless taken up. One critical competence of nations is their relative ability to turn inventions into new products and services, new lines of business, and entirely new enterprises, even entire industries. No nation can create sustainable new businesses without creative, bold, motivated, and determined individuals. And yet, no such university programs exist that would produce doctors of business creation who can actually "cure patients".

This conceptual article depicts a concrete solution: the concept for a globally distributed, enterprise-centric, entrepreneurial-faculty-driven, open-innovationbased, and social-media-empowered university entity a new-generation private public partnership and "Living Lab 2.0" - referred to as Kalevala Global Business Creation School. The conceptualization derives from observations and action research around the Global Venture Lab (GVL; gvl3.com) Finland experiment at the University of Jyväskylä (jyu.fi/en/), from 2007 to 2011. In 2010, the term "Art of Business Creation" was coined by GVL Finland as a new domain needed to complement the science of business administration.

GVL Finland set out to enable the solving of big ecological and societal problems via university-based growth venture creation. This was sought after by integrating research, education, and innovation - and working on a vision of universities as one global business-creation platform. In the process, the role and nature of university faculty had to be re-evaluated, and the concept, criteria, and forms of knowledge reconsidered. Important encouragement and inspiration was received from interaction with various representatives of the Finnish Funding Agency of Innovation and Technology (TEKES; tekes.fi/en/) and the European Institute of Innovation and Technology (EIT; eit.europa.eu) and with the co-founders of the University of California, Berkeley (berkeley.edu) coordinated Global Venture Lab Network, between 2007 and 2011.

\section{Philosophical Foundation}

As per GVL Finland terminology, global business creation is herein defined as "the determined (joint) action of various stakeholders to swiftly and maximally realize recognized global business opportunities by fully utilizing the vehicle value of incorporation." Overall, this article subscribes to the sentiments of The Kauffman Thoughtbook (2011, tinyurl.com/72rfxtu): "to think differently and turn creative insights into practical, sustainable solutions".

In this article, entities, especially business firms, are viewed as the vehicles of their owners. According to our point of departure, the responsibility of the owners for the success of a venture is undividable. Luckily, we say, ownership can be divided - even if this should not be approached lightly. In this article, ownership is thought of as "venture parenthood" with a clear distinction made between active and passive shareholding. Whereas founding owners are thought of as biological parents and other active owners as step-parents, passive shareholders are thought of as anonymous "donors" of sorts, at best. Venture capitalists are stepparents dedicated to rapidly preparing venture babies, those both willing and able, for the cold world of faceless donors. Whereas natural persons are, by definition, limited to two biological parents, ventures importantly - have no such limitations.

Even if owners carry an undivided responsibility for venture success, they typically have to limit their absolute decision power, over time, by allowing for contractual arrangements with various stakeholders, such as customers, employees, financiers, and subcontractors. Owners often also appoint representatives in their stead, for example, as members of the board and CEO. Nonetheless, companies and organizations, and their actions and doings, are viewed herein as the footprints of their owners aimed at fulfilling their interest, mission, or purpose. The mission can be clear or unclear, open ended or short term, direct financial, indirect strategic, or social but it is - at any rate - always set by the owners as "venture parents".

This article draws from the paradigm building around venture-to-capital (V2C) or knowledge investing and more recent work on the "who-do" framework (eBRC, 2006; tinyurl.com/7plzhmw). Originally, this work is rooted in the corporate strategy literature and the interest in linkages between ownership and strategy (Seppä, 2000; tinyurl.com/87acfec). Therein, understanding the global dynamism between who (exactly) owns an entity and what it can do - in order to maximize success - is the focus.

Based on the literature referred to above, Figure 1 illustrates the four main owner categories of growth ventures, referred to as the "principal venture parents". The principal venture parents are divided into those 


\section{The Case of the Kalevala Global Business Creation School}

\section{Marko Seppä}

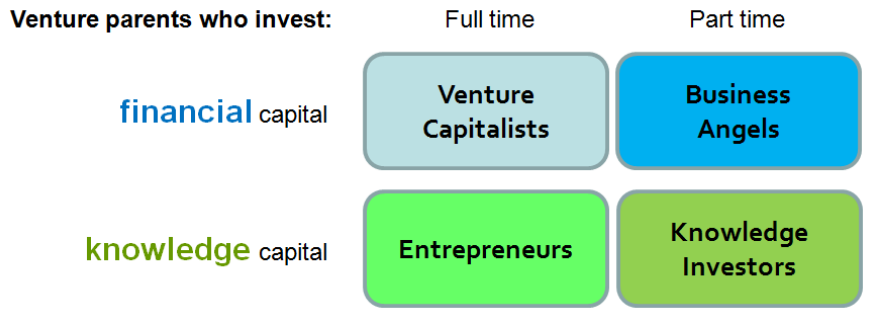

Figure 1. The main categories of venture parents

gaining their parenthood by primarily investing financial capital and those primarily investing knowledge capital. The former group of venture parents builds the bridge towards passive shareholders who do not interfere with "parenthood". An interesting archetype for a venture parent is a venture capital firm that is fully managed by salaried employees.

The roles of entrepreneurs and venture capitalists as well as business angels have received due attention in the literature, which is also reflected in economic policies. The full potential of actors referred to as knowledge investors is yet to be discovered. Kalevala Business Creation School would focus on maximally utilizing this potential.

Methodologically, this article leans on action-research methods where scholars are themselves participants and actors in the phenomenon under investigation. At an extreme, such scholarship requires a double competence, practical as well as academic. Consequently, the best action scholars and educators challenge the popular claim: “Those who can't do business, teach it". To be sure, the desire to tackle this punchy claim is written deep in the "DNA" of Kalevala Global Business Creation School.

\section{From Business Administration to Business Creation}

One hundred years ago, scientific management gave the answer to the question of how to organize for economies of scale and the heyday of industrialization. The functions of management and classic disciplines of business administration became well anchored and defined over the course of the 20th century. The classic functions are still being underscored by business schools that are producing masters of business administration all over the world.
What would Frederick Taylor - the "father of scientific management" (tinyurl.com/yuqhv9) - prescribe for the metal workshops with decreasing order books or the paper industry facing a world of ecological pressures? He might see the vast opportunities vested in empowering each individual - from employees to all other stakeholders - within a company's reach. He might ponder how to increase everyone's "knowledge investment" and passion for the company mission how to engage everyone in (business) creation, rather than subject them to (business) administration.

To equip graduates with what it takes to create businesses in the Google era, The University is expected to renew itself, and the business school, accordingly. There is a call for ever more ambitious and ever more creative, holistic, and global - university programs. The call is for approaches that (factually) integrate education, research, and innovation (i.e., the knowledge triangle) around business creation into dynamic, multidisciplinary, open-innovation-based, real-life experiments, referred to as "Living Labs" in Europe.

The whole world talks about innovation. Innovation is "the word". But what is innovation; what is it made of, essentially? Innovation is great ideas with proven economic value. Put bluntly, innovation is a commercialized invention. Many who talk about innovations effectively talk only about inventions or technological inventions, to be more precise. Very few talk about the commercialization end of innovation.

It appears to be somehow noble to deal with invention and somehow lowly to deal with commercialization. The former creates something new, we easily think, and the latter steals it away by charging the maximum a customer can pay - not the minimum needed for production. The former captures the essence of capitalism, the latter of socialism. Both require management and can benefit from professional business administration.

In the words of a frustrated rocket scientist colleague: "Hey, come on, business creation is not rocket science". Indeed, in our words, it is more complicated than that. Rocket science is connecting "compatible dots" under the rationality and logic of natural science. Business creation increasingly involves connecting "incompatible dots": systems far more complicated than in rocket science, namely human beings, time, 


\section{The Case of the Kalevala Global Business Creation School}

\section{Marko Seppä}

money, machines, a good day and a bad day - "minds and matter" - and all this across vast cultural and physical barriers.

There is call for ever more deeply interdisciplinary foundations from academia, by the society at large, for ever more intimate - bolder, deeper, and ever more creative - interaction with practitioners of both established and emerging companies. Such new programs are under way in several universities around the world.

\section{Kalevala Global Business Creation School}

The objective, herein, is to conceptually depict a new breed of university entity: a globally distributed "business creation school". This is not something better or more important than the classic business administration school, but something supplementary. The entity is named "Kalevala" as a tribute to the Finnish national epic (tinyurl.com/yedcg8), which builds on the power of knowledge and knowledgists over swords and muscles and the quest for a machine of eternal wellbeing, instead of a source for world dominance, as the end goal. The term "global" stands for the challenge to create a globally shared businesscreation platform.

The conceptualization of the "Kalevala Global Business Creation School" draws from the GVL Finland experiment from 2007 to 2011 (gvl3.com) and the eBRC program from 2001 to 2005 (ebrc.fi). While eBRC was a research intermediary leaning on a triple-helix model and the integration of business, university, and government, with emphasis on research, GVL Finland was a business-creation exercise integrating the three corners of the knowledge triangle, namely research, education, and innovation, with emphasis on education. Going forward, it is only logical that the emphasis will be on innovation (or business creation).

Kalevala subscribes to open-innovation thinking, but with the creation of businesses and the launching of new ventures at core, it is fuelled by the concept of knowledge investing (or V2C investing), which is of kin to sweat-equity investing. The fact that business creation requires co-creation by an ever-larger and dynamically evolving body of owners, rather than a single principal or a small team, does not make ownership unimportant. It makes it all the more important and all the more complicated to handle. The complicated linkage between the source and ownership of an invention versus the value of commercialisation (business creation) effort, and the split of eventual proceeds is to be respected and attended at all times.

There are four key inputs and four key outputs in the Kalevala process, as illustrated in Table 1. In the subsections that follow, each input and each output is briefly introduced.

\section{Input 1: Faculty - from a bottleneck to enabler}

The faculty members of the Kalevala Global Business Creation School are practicing business creators themselves and represent scholarly backgrounds (i.e., academic disciplines) across the board. They study and teach business creation by creating businesses, as coentrepreneurs to practicing entrepreneurs and each

Table 1. Inputs and outputs in the Kalevala process

\section{Inputs}

1. Global partnership between faculty (profs, doctoral students and lecturers)

2. Dedicated students in each committed university location

3. Curious inventors and entrepreneurs (as live case material)

4. Practitioners and corporate partners (as knowledge and resource investors)

\section{Outputs}

1. New products, businesses, and enterprises (as research outcomes)

2. Willing and able co-creators of global businesses and enterprises

3. Great global enterprises that solve "big problems"

4. Return on investment for every involved person 


\title{
The Case of the Kalevala Global Business Creation School
}

\author{
Marko Seppä
}

other, continuously and across all borders. Importantly, this new breed of faculty bridges all existing domains (and silos) of knowledge with the real world, thereby turning faculty, at large, from a bottleneck to enabler.

\section{Input 2: Students - from passive learners to "dream labour"}

One cannot learn without motivation. This holds true for business creation, in particular. Even in no-tuition university environments, students can be turned from passive to energetic, heavily engaged action learners by offering them real-life challenges and special ownership-related responsibilities and incentives. The curiosity, creativity, and energy reserves of students can turn them into "dream labour" and Kalevala Global Business Creation School into a "dream factory".

\section{Input 3: Entrepreneurs - from single mothers to} networked parents

The Kalevala Global Business Creation School offers entrepreneurs a globally distributed Doctor of Business Creation (DBC) program whereby they can explore ways and forms of shared venture parenthood in an experimental environment at, nevertheless, market terms. Also entrepreneurs that are not interested in pursuing their own DBC can offer their ventures as live case material and participate in the shared ventureparenthood programs. This helps entrepreneurs transform from single mothers to networked parents.

\section{Input 4: Executives - from mentors to co-entrepreneurs} The Kalevala Global Business Creation School pools individual executives for a new role and capacity: that of knowledge investors. The school offers the busiest of professionals precision in terms of use of time and effort and most lucrative risk-return prospects. The executives are also offered opportunities to engage the organizations they represent in global business creation as resource investors. Overall, this expands the scope of alumni and other professional participation, in university-based business creation, from mentors to coentrepreneurs.

Output 1: Products and businesses as research outcomes On the ground level, the Kalevala Global Business Creation School produces new products, businesses, and enterprises as basic research outcomes. Even if the aim is always for world-class businesses, there is no guarantee that any hugely successful enterprises will emerge. Instead, tolerance for failure must be guaranteed. A significant level of trial and error is needed to enable the second, far more important output.
Output 2: Willing and able global business creators The Kalevala Global Business Creation School produces "battle-tested", willing, and able co-creators of global businesses. This is a level where a world-class standard can be achieved from the get-go, regardless of the level of actual business success with the bottom-level output, described above. The possibility to experience and learn from failure is, in fact, more important than business success, on the bottom level. The participating universities can supply their home regions and enterprise environments with globally connected, ready-to-go business creators.

Output 3: Great global enterprises

All action in the Kalevala Global Business Creation School is targeted at producing great global enterprises, ones that solve Big Problems. While it is not imperative that such solutions emerge, it is all the more likely that this will happen. The pressure is off, but every passion is on. All the resources of this globally distributed community, platform, and factory of business creators and the knowledge they need, is always targeted to the most promising target ventures, across all borders.

\section{Output 4: Return on investment for every involved person}

For each global growth venture success story produced by Kalevala Global Business Creation School, return on investment will be distributed to every involved person. The guiding principle is globally shared parenthood of all ventures and, even if some (locally leading) individuals will always own, contribute, and receive far more than the others, everyone will have a small slice of everything.

\section{Discussion and Conclusions}

Rapidly growing companies and the jobs they create are the lifelines of contemporary societies around the world. While basic manufacturing and other labourintensive domains still work for Asia, societies in America and Europe must move further upstream. While market orientation saves a lot for America, Europe faces an ever tougher challenge. We must move upstream in both the intensity of business knowledge and in mindset quality.

All said, one should wonder why there is no university domain focused on producing growth venture creators and the type of knowledge they need to create great enterprises. Universities do have research on growth ventures, and professors of such research, and they do educate more such researchers, but few universities 


\section{The Case of the Kalevala Global Business Creation School}

\section{Marko Seppä}

produce "clinical doctors", individuals willing and able to co-create global growth ventures. Universities do have the best practice of bringing in entrepreneurs-inresidence, but this is only a quick fix and saves universities time from having to actually accept new, uncomfortable traditions.

In our time, universities could offer a globally distributed doctoral program in growth venture creation, one that produces "doctors that cure patients" in market conditions and on a shared enterprise platform. Such new breed of students would produce unique theses (of art, rather than science), while co-creating live case ventures across all borders and barriers, as co-entrepreneurs together with business creation professors, in a process open to wider such education and subject to such knowledge creation where the end justifies the means, complementing the tradition where "the means justify the ends".

To be sure, there are no internal pressures or any natural evolution that would cause universities to change the status quo. The demand for the universities to produce growth venture creators and "doctors of business creation" by professors who themselves "cure patients", in extreme action learning and action research environments, is increasingly voiced by the industry and policymakers, all over the world. But the willingness and ability of the universities to change, from within, is hypothetical only. Masters of business administration may theoretically understand that we need masters of business creation, but they have a hard time depicting how, and by whom, such masters could be produced in practice and - more importantly - how, and by whom, not.

History will be made by the decision makers and universities who dare to lead us in this new space. With reference to how global the playing field of growth venture creation has become, and how imperative it would be to build this "new domain of knowledge" on a globally shared enterprise platform, this takes more than a standard appointment of new professors. To learn and teach global growth venture creation, they have to do it.

\section{About the Author}

Marko Seppä is "serial co-creator" and knowledge investor specialized in growth venture creation. He was apprenticed as venture capitalist by Panostaja Group, in Finland in the late 1980s. Since 1991, he has led the co-creation of three enabler organizations: FVC, a pioneering venture capital firm for the emerging markets of Russia and the Baltic countries; eBRC, an ambitious e-business research center for a local pilot of eEurope; and GVL Finland, a global venture lab experiment for University Alliance Finland. He holds an MSc in Management from the University of Tampere and a $\mathrm{PhD}$ in Corporate Strategy from the University of Jyväskylä. He is currently engaged in the co-creation of Global Enabler: A community, platform and factory of enablers of global business creation for problems worth solving.

Citation: Seppä, M. 2012. From Business Administration to Business Creation: The Case of the Kalevala Global

Business Creation School. Technology Innovation

Management Review. June 2012: 6-11. 